\title{
Bufão: máscara e conexões rituais
}

\author{
Buffoon: masks and ritual conections
}

Joice Aglae Brondani ${ }^{1}$

1.

Pós-doutorado na Universitá

di Torino, Dipartimento

di Letteratura e Cultura Straniera (bolsa CAPES).

RESUMO

O presente artigo traz considerações sobre a máscara do bufão. Pós Doutorado na Universidade Federal de Uberlândia-MG, no Instituto Coloca esta em relação com um universo sensível, numinoso, xamânico e mítico e estabelece conexões com Dionísio, Exu e Sátiro, buscando sublinhar as potências de incorporação dos princípios grotescos, carnavalescos e ritualísticos desta máscara. de Artes (PRODOC-CAPES) ORCID: http://orcid.org/ 0000-0002-4035-583X . Contato: Palavras-chave: Máscara. Ritual. Bufão.

\section{ABSTRACT}

This article presents considerations about the mask of buffoon. Places it in relation with a sensitive, numinous, shamanic and mythical universe and establishes connections with Dionysus, Exu and Satyr, seeking to underline the powers of incorporation of the grotesque, carnival and ritualistic principles of this mask.

Keywords: Mask. Ritual. Buffoon. 
No presente artigo escrevo sobre o Bufão, uma compreensão que foi sendo construída ao longo de um transcurso de formação e pesquisa no universo da Máscara. A pesquisa é legitimada em devaneios ${ }^{2}$, na concepção de imagem/imaginário/Fundo Comum dos Sonhos em Bachelard³, atravessada, afetada e comovida por uma compreensão mítica da máscara, tendo como princípio fundante conectividades em diversas instâncias com a tríade Jogo-Festa-Ritual de Huizinga4 .

A busca pela compreensão do universo da máscara começou a partir do palhaço/clown. Foi uma exigência da própria máscara a busca pela compreensão de seu oposto complementar: o Bufão, cuja concepção, nessa compreensão, é uma máscara - porém uma máscara de corpo inteiro, uma máscara física ou corpo-máscara.

Costumo afirmar que enquanto o palhaço vai em direção a uma poesia apolínea, o bufão vai em direção a uma poesia dionisíaca e ambas se relacionam, fazem parte de um mesmo fluxo, são complementares e opostos, se pertencem, se completam, se potencializam e se misturam. Nesse caminho entre o bufão e o palhaço, estão as máscaras dell'arte ${ }^{5}$ - as quais serão citadas ao longo do artigo, embora não se vá adentrar à Commedia Dell'Arte propriamente dita6.

É necessário dizer que a máscara do bufão possui dois tipos de compreensão e organização: ritualística e mercadológica - tal qual as máscaras dell'arte e o palhaço. A organização mercadológica ou do espetáculo não renuncia ao lado mítico e místico da máscara e vice-versa. É preciso considerar que depois que subiram aos palcos e ganharam as cortes, as máscaras sofreram desdobramentos ou mudanças. Na linha na qual procuro desenvolver minhas experiências cênicas e reflexivas, tenta-se compreender como a máscara tomada por um profissional pode trazer consigo uma forte emanação energética festiva ritualística. Tal compreensão se dá a partir de conexões com o universo imaginal, numinoso, sensorial, energético e espiritual, ou seja, através de subjetividades.

Sob a compreensão dessa pesquisatriz ${ }^{7}$, as máscaras são como ícones, uma espécie de portais de acesso a todo um universo imaginário, a toda uma forma de compreensão de mundo. Esse universo se concretiza no objeto/link máscara e se reafirma em uma máscara física ou corpo-máscara ${ }^{8}$, bem específica no caso da Commedia Dell'Arte ${ }^{9}$ e construída/descoberta, nos casos do bufão e palhaço/clown ${ }^{10}$.

A preparação técnica do ator que irá portar a máscara, tanto o objeto, quanto a física, é específica, pois é necessário um corpo diferenciado energeticamente e tecnicamente preparado (não adentrarei à técnica de bufão construída, pois
2.

O devaneio é a capacidade de conceber na imaginação, agir em uma outra instância que não a da realidade, de sonhar acordado. Para saber mais, ler "A terra e os devaneios do repouso", de Gaston Bachelard (1990).

3. Para saber mais sobre a imagem, imaginário e Fundo Comum dos Sonhos, ler "O direito de sonhar", de Gaston Bachelard (1986).

4.

Para saber mais sobre a tríade mencionada, ler "Homo Ludens. O jogo como elemento da cultura" de Johan Huizinga (1993).

5.

Para saber mais sobre uma possível relação entre sátiros, bufões, máscaras da Commedia Dell'Arte e palhaço/clown, ver Brondani (2012).

6.

Interessados em saber sobre Commedia Dell'Arte a partir da compreensão desta pesquisadora, ver Brondani (2008; 2012; 2013; 2014). ᄀ.

O termo pesquisatriz passou a ser utilizado em minha tese de doutoramento (2010). Em 1994 a pesquisadora Beti Rabetti já tinha utilizado o termo pesquisator.

8.

Doravante sempre que enunciado corpo-máscara ou máscara física, entende-se que são sinônimos.

9.

A prática de Commedia Dell'Arte que me interessa é a continiana: ela guarda aspectos grotescos, carnavalescos e ritualísticos. Integrei a Scuola Sperimentale dell'Attore (Pordenone-IT) durante os anos de 2008 e 2009, fazendo minha formação com Claudia Contin e Ferruccio Merisi, sendo atriz da companhia e ministrando cursos. De 2010 a 2014 fundei e integrei a Bottega Buffa CircoVacanti (Trento-IT), grupo de Commedia Dell'Arte atuante na Itália.

10.

Doravante entende-se que clown e palhaços são sinônimos, não adentrando em discussão sobre os termos. 
ficaria um artigo longo demais ${ }^{11}$ ). A noção de corpo linkado com o universo da máscara já estava presente na prática da máscara do clown, porém, foi no trabalho intenso com o bufão (2006) que aprofundei o conceito e prática de máscara física. A máscara física é um processo que coloca todos os potenciais da máscara na musculatura, em circuito muscular e energético. Um processo em que a imagem poética vindoura do Fundo Comum dos Sonhos inunda e habita o corpo do pesquisator/pesquisatriz em image/in/ação, agindo em subjetividades e transformando esse corpo por meio de um Fundo Poético Comum (LECOQ, 1997) ${ }^{12}$.

A máscara física é como um conjunto de corporeidades, um agenciamento de energias potenciais. Segundo Burnier, fisicidade é a forma dada ao corpo, enquanto que a corporeidade é a forma habitada pela pessoa (BURNIER, 2001). A máscara física são os circuitos energéticos e musculares potencializados e habitados não somente pela pessoa, enquanto consciência, mas com subjetividades vindouras do Fundo Comum dos Sonhos agenciadas pelo Fundo Poético Comum. Essas potências, juntas, constituem um link para adentrar o universo do imaginário.

Com a máscara objeto tem-se o fetiche, isto é, dá-se um poder ao objeto máscara. A máscara física é o complexo Fundo Comum dos Sonhos e Fundo Poético Comum que ativará uma outra corporeidade, a qual dará o "poder" ao sujeito. O sujeito possui uma fisicidade e corporeidade própria, a qual receberá, por meio do Fundo Poético Comum (dos impulsos de criação), a fisicidade e a corporeidade da máscara - com conexões com o Fundo Comum dos Sonhos. Trata-se de uma comunhão de corporeidades que atuam com influição. A máscara física é constituída pelo circuito muscular, o qual é formado por pontos de tensões e energias - circuito energético. Uma vez acionadas as tensões, formando o circuito muscular, se desencadeará o circuito energético e ambos, na corporeidade própria do sujeito, formarão a corporeidade da máscara física e, uma vez tido esse conjunto, o corpo máscara deve funcionar como link para o universo do imaginário - do mesmo modo que a máscara objeto.

A Máscara do Bufão prende impulso no universo do imaginário, pois, transbordante e em metamorfose pela própria natureza do excesso, é impossível deixar de relacionar o bufão com o caldeirão em ebulição que é o imaginário, que é o Fundo Comum dos Sonhos.

Nessa dinâmica entre Fundo Comum dos Sonhos e Fundo Poético Comum, a máscara não é simples adereço, é travestimento completo do ator, no sentido de alterar e mudar a natureza, pois, no corpo máscara, tem-se ação no corpo inteiro. Essa característica da máscara física é o que faz a diferença
11.

Para saber mais sobre a técnica de bufão mencionada, ver Brondani (2014).

12.

Para saber mais sobre a dinâmica entre Fundo Comum dos Sonhos e Fundo Poético Comum, ler referência citada na nota 10 . 
para o ator que trabalha com as máscaras dell'arte, bufão e palhaço (sempre na concepção da autora, a qual concorda com Taviani, Martin, Molinari, Tessari, Fo, Lecoq, Meyerhold, Duchartre e Contin).

Tentarei fazer uma rápida exemplificação sobre a relação entre máscara objeto e máscara física. Na Commedia Dell'Arte tem-se a ação da máscara no corpo, transformando-o em máscara física. Porém, o corpo máscara não cristaliza o corpo em uma determinada postura, nem o ator deve agir como se fosse uma deficiência ou limitação. A máscara física não impede o ator de realizar nenhum movimento ou ação; ela é, na verdade, um incentivo ao desenvolvimento de potências. $\mathrm{O}$ ator deve redescobrir as possibilidades do seu corpo dentro daquela fisicidade e corporeidade, tendo a imagem de um corpo elástico, fazendo tudo como qualquer outro corpo, porém, a partir da lógica físico-corpórea da máscara. Com a máscara física, o ator deve desenvolver ainda mais as suas capacidades, não fazendo dela um limite, mas sim, uma chance de novas explorações.

Molinari, Tavani e Fo também compreendem o bufão como máscara, como corpo-máscara, por tudo o que é pertinente à máscara, pela ligação com o ritual, com Dionísio, com o travestimento e a metamorfose. Martin e Lecoq também são da mesma opinião e acrescentam que se trata de uma máscara que comove todos os sistemas orgânicos do corpo.

Herdeiro dos Sátiros e Dionísio - deus das transformações da terra e do tempo, da metamorfose, da fertilidade, da vida e da morte - o bufão comporta genes de um DNA imaginal que atua em seu corpo (imaginação/dinâmica entre Fundo Comum dos Sonhos e Fundo Poético Comum). A partir deste DNA imaginal que percorre a história da humanidade e muito além dela, adentra-se as considerações sobre as conexões ritualísticas do bufão e busca-se fazê-lo através de um nó da rede conectiva que estende fios desde a Grécia Antiga. Para vislumbrar tal rede, é necessário que consideremos as representações teatrais, trágicas e cômicas, do séc. V a.C. em Atenas e Grécia, como formas já elaboradas e maduras do teatro, para, então, conjecturar sobre relações conectivas mais antigas.

Molinari, através de estudo iconográfico, traz a informação de que os povos primitivos, antecedente ao séc. $\mathrm{V}$ a.C., já faziam uso do "elemento teatral primordial", ou seja, do travestimento/mascaramento. Tal elemento já era usado nos cortejos ritualísticos em honra ao deus Dionísio (MOLINARI, 2007). Fazia parte destes rituais da Grécia antiga o Sátiro, o qual portava o "elemento primordial do teatro" e já era visto como corpo-máscara, como ser fantástico metade gente metade bicho, representante dos antigos espíritos da natureza e do próprio Dionísio. 
Dionísio era a divindade que catalisava "diversas funções da mente primitiva" e tinha o "poder intoxicador da procriação em todas as coisas". Apesar de ter sido gerado à imagem e semelhança do homem, era chamado por muitos nomes - deus touro, deus bode, deus do vinho - e quando se apresentava como deus do vinho "exprimia um aspecto simbólico de sua divindade energética" (GASSNER, 1974, p. 13). O povo primitivo era mergulhado em magia e ritualidade.

Os rituais à Dionísio, chamados ditirambo, tinham, inicialmente, somente o canto; pouco a pouco foram sendo acrescentados a dança e a música (COSTA; REMÉDIOS, 1988). Com a dança os integrantes chegavam ao êxtase e ao transe (BRANDÃO, 1980). Já nesses cortejos existia o travestimento: homens se mascaravam em peles de bode e ofereciam ao deus um sacrifício animal - geralmente um bode. O povo primitivo era mergulhado em magia e ritualidade.

Foi a partir do ritual do ditirambo que os primeiros elementos da tragédia se desenvolveram. No séc.VI a.C., Simonide de Céos (556-468 a. C.) apresentou o coro e um solista (o corifeu) que dialogava com o coro. Posteriormente, em 535 a.C., com Téspis e Pisístrato, o ditirambo passou a contar não somente sobre Dionísio, mas também a mitologia de outros deuses "profanos". Quando os temas foram variando, então, é que começaram a ser estruturadas a tragédia e a comédia (PAVIS, 2005).

Uma das lendas sobre o mito de Dionísio conta que foram os Sátiros e as Ninfas que cuidaram do deus, seguindo ordens de Zeus (GASSNER, 1974). No ditirambo existia o travestimento com peles de animais, representando os Sátiros - seres que incorporavam e representavam o deus do vinho. Tanto quanto os Sátiros, os quais eram concebidos pela imaginação popular como "homens-bodes" (BRANDÃO, 2007), aqueles que se travestiam de Sátiro se tornavam Sátiro e essas representações sobre representação se tornaram tão mitológicas quanto o próprio Dionísio. Pode-se perceber em iconografias que os Sátiros foram, muitas vezes, pintados de forma mitológica. Sempre presentes em rituais religiosos e teatrais, os Sátiros seguiram a evolução do coro na tragédia, para os dramas satíricos e para a comédia - eram como atores e/ou adoradores do deus do vinho travestidos (MOLINARI, 2007) no mito. Essa mistura de travestimento e mitologia é interessante, pois em muitos rituais acontece o travestimento para a possessão e incorporação do mito, como também pode haver o travestimento somente para caráter representativo do mito.

De certo modo, as cerimônias ritualísticas em honra a Dionísio foram o caldeirão fecundo da civilização ocidental. Mimos, clowns, saltimbancos, bufões e commedianti europeus derivam dos Sátiros (WILLEFORD, 1998; FO, 1997). Compartilhando desse fértil pensamento, o Sátiro, então, fecundou muitas outras 
manifestações lúdicas. Dionísio, o deus da metamorfose, transmutação e transformação da terra e do tempo, da semente em planta e alimento, da morte e da ressurreição, é intensamente conectado ao Sátiro, que, por sua vez, é conectado ao bufão, e ambos incorporam tudo o que é pertinente ao deus.

A Máscara do Bufão dá continuação à força engendradora e traz em si embriões de diversas manifestações e linguagens cênicas fomentadas no coro dos Sátiros - os cortejos ritualísticos e teatrais dos homens bodes fortalecem a imag/in/ação do coro de bufões. Se de um lado tem-se uma possibilidade conectiva entre Sátiros e bufões numa evolução do coro, do outro tem-se uma possibilidade imaginal, considerando como premissa a dinâmica entre o Fundo Comum dos Sonhos e Fundo Poético Comum e conectividades com a tríade Jogo-Festa-Ritual.

O coro de bufões, de certa forma, dá continuidade ao ditirambo. Em um processo de evolução da estrutura e com força criativa, as transformações dentro da parte lúdica e de travestimento do coro foram trazendo não somente "homens-bodes", mas outros animais como o touro e o asno. Mais tarde, juntamente com a força carnavalesca, outros tipos de travestimentos e travestidos foram se integrando ao cortejo. A relação entre Dionísio, os Sátiros, o ditirambo, o coro das tragédias e daí, então, evoluindo juntamente com o teatro, para a comédia, se deu em um avançar da história, transporte e transformação do ritual para o teatro.

Nos festivais de teatro, o drama satírico, o qual se desenvolveu do ditirambo, era a quarta parte do conjunto de peças que um autor apresentava - três tragédias e uma comédia. Com caráter farsesco, trazia mesclado o religioso e o profano e fazia paródia dos heróis trágicos. A comédia, tanto quanto a tragédia, também teve transformações (BRANDÃO, 2007). No primeiro momento, a "Comédia Antiga" era composta pelo "kômos" e pela farsa. O kômos se desdobrava em profano ou dionisíaco (parte religiosa). o kômos dionisíaco religioso era um ritual em que um falo era carregado, em procissão, pelas ruas da cidade, como parte dos rituais de primavera, semeadura, fertilidade e fertilização da terra. O kômos profano consistia em um grupo de pessoas que saíam pelas ruas e casas pedindo doações e zombando dos moradores; era a imitação, paródia e sátira do kômos religioso e, para não serem reconhecidos, se travestiam em peles de animais.

Muito provavelmente o coro dos bufões seja oriundo desta via dupla do kômos, colocando em parceria e comunhão o profano e o religioso, o que reforça a observação de que, para o bufão, jogo/cena/comédia e sagrado/drama/tragédia possuem o mesmo peso (PEZIN, 2003). 
O coro de bufões une os dois kômos, o falo, o ritual, a zombaria, a paródia, a sátira e a extrapolação da realidade por meio do excesso e gratuidade. É interessante observar que o falo que acompanhava os coros da comédia e cortejos carnavalescos, um dos elementos obscenos do coro, segundo a moralidade social, é oriundo da parte religiosa do kômos, e não da profana. Esta via dupla entre religioso dionisíaco e profano zombaria que o bufão porta com ele é o que o torna tão ambivalente, inquietante, metamorfoseante, transformador, divino e infernal - no sentido transtornador do termo, não de bem e mal.

As representações dos gêneros trágicos e cômicos se moveram da Grécia Antiga para a Roma Antiga (CHACRA, 1983) e tiveram desenvolvimentos enquanto movimentação, caracterização e evolução do coro ditirâmbico, na tragédia e nas três fases da comédia (grega antiga, do meio e nova), até se desdobrarem nos estilos populares: atellana, fescenino e mimo. A comédia atellana, a qual tinha como núcleo as máscaras de um velho (Papus) e de um servo (Maccus), é facilmente identificada como uma possível origem das máscaras do servo e do velho da Commedia Dell'Arte (Zanni e Pantallone), enquanto o mimo é associado ao estilo satírico e ao giullari/buffone/bufão (MOLINARI, 2007). Essa relação do mimo com o drama satírico reforça a conexão do coro dos sátiros com o coro dos bufões/giullari.

Conhecendo um pouco das transformações do coro ditirâmbico e transcursos dos Sátiros, pode-se entender que os coros satíricos, trágicos e cômicos fortaleceram a festa carnavalesca, se perpetuaram nela se desdobrando. O coro que na tragédia acompanha, narra e até compartilha da experiência trágica, também se oferece no banquete carnavalesco. É necessário considerar que o coro dos Sátiros, tanto na tragédia, quanto na comédia, já trazia em seu cerne os princípios carnavalescos e do baixo ventre - maior força do popular (BAKHTIN, 1999). É de grande importância a compreensão da transformação do coro satírico, o qual pertencia ao drama satírico, oriundo do ditirambo onde religioso e profano comungavam no kômos, para o coro bufonesco. A partir dessa constatação, percebe-se que o coro do drama satírico possui muitas características do coro de bufões. Os bufões são representações de um imaginário que transborda, que excede e que renova. Representam a síntese de uma compreensão de mundo e quem porta tal máscara deve vestir tal compreensão.

O carnaval, em sua tradição europeia primitiva, ligado à semeadura e equinócio de primavera (para quem está saindo do inverno e passando para a primavera), representa o renascimento da vida após a hibernação do inverno. Tal representação 
de renovação também se dá por meio do travestimento/mascaramento. Mas, o ato de se travestir/mascarar é ambíguo naturalmente, uma vez que traz em si verdades diferentes em uma união entre realidade e imaginação.

[...] os corpos são verdadeiras máscaras, a materialização das forças que portamos em cada um de nós, força das paixões, da violência, dos excessos aos quais somos capazes. Seres cômicos, primitivos, de natureza divina e animal, divertidos e fascinantes, mágicos ${ }^{13}$ (MARTIN, 2003, p. 27).

Uma outra manifestação que influenciou e se misturou ao bufão, também advinda dos coros dos Sátiros, foi o mimo. Porém, o Sátiro se travestia parecendo um animal, e influenciou o bufão com seu travestimento, enquanto o mimo se apresentava sem máscara e sem travestimento animalesco. Tanto o Sátiro quanto o mimo, no entanto, utilizavam de todas as capacidades de seus corpos. De acordo com Molinari (2007), há uma generalização na Idade Média, na qual os atores que não faziam uso de máscaras eram vistos como herdeiros do mimo e chamados de histrioni/histriões, enquanto qualquer ator que se apresentava em ruas, bares e feiras era chamado de giullare/ bufão, menestréis e trovadores, dependendo da especificidade, sendo que giullare era o modo mais difuso e complexo, uma espécie de mistura entre mimo e sátiro:

E o ator, o giullare é aquele cuja atividade profissional consiste na distorção da forma humana e não somente porque ele se traveste de animal ou mulher, que por si só comporta a corrupção moral, o que é hipocrisia e bajulação, mas, também, porque ele usa o seu corpo, exibindo-o, contra as normas naturais e sociais $^{14}$ (MOLINARI, 2007, p. 58).

Pode-se encontrar, em alguns textos, a tradução de giullare como jogral, mas a forma/versão do jogral que ficou mais conhecida é aquela após o século $\mathrm{X}$, muito mais próxima dos trovadores, que declamavam poesias, cantavam e tocavam trovas. O que é importante saber é que o jogral com essas características, e após o séc. X, é uma das evoluções ou desdobramentos do giullare/bufão (MOLINARI, 2007).

Uma característica que não é uma regra geral, mas, também, não é exceção, é que as vezes o giullare se movimentava sozinho, mas é preciso entender que, vindo da classe popular e sendo portador da "cultura da classe popular" (CAMPORESI, 1991), o bufão sobrevivia da sua arte e com isso, muitas vezes, dependia de alguém que o mantivesse. Seria muito mais provável e possível obter um mecenas ou benfeitor se estivesse só. Mas, mesmo perambulando só, o bufão mantinha suas linguagens - zom-
13.

Tradução da autora:

"[...] les corps sont de véritable masques de jeu devirent la matérialisation des forces que nous portons tous en chacun de nous, des passions, de la violence, de la démesure dont nous sommes capables. Êtres cosmiques, primitifs, de nature divine et animale, amusants fascinants, magiques."

14.

Tradução da autora:

"E l'attore, il giullare é proprio colui la cui attività professionale consiste nello stravolgimento della forma umana, e non solo perché esso si traveste da animale o da donna, ciò che di per sé comporta corruzione morale, cioè ipocrisia e adulazione, ma anche perché egli usa del suo corpo, esibendolo, contro la norma naturale e sociale." 
baria, festa, carnaval, escárnio, escatologia, grotesco, sexualidade, divino e profano - e o riso em todas as suas possibilidades. Se necessitava ter força, o bando/coro se formava, gerando as festas de loucos, carnavais, cortejos etc. Se a estratégia era sobreviver, o melhor era perambular só. Na verdade, sua solidão protegia os nobres e clérigos de sua força carnavalesca e antropofágica, a qual estava presente, mas em menor potência. A corte não conseguiria arcar com o coro de bufões sem se corromper ou virar alvo, pois quando um bando ganha espaço a folie do carnaval, a loucura libertadora, se instaura.

Os bufões/giullari tinham três formas de jogo/cena. A primeira era com gestos obscenos, corpos deformados, transformados e transfigurados. O segundo tipo de jogo era realizado nas cortes e os bufões denunciavam ou criavam intrigas (o que nós conhecemos como bobo da corte ou louco do rei). O terceiro jogo acontecia nas igrejas e os bufões cantavam/contavam a vida dos santos, reis e príncipes.

É natural pensar que o bufão iria procurar a igreja: já que sua ascendência está nos rituais a um deus ele se infiltrou nas instituições religiosas, mantendo seu vínculo com o divino. Naquele momento histórico da passagem do primitivismo à Idade Média, em que a sociedade estava se apoderando dos rituais chamados por ela de profanos e transportando-os para festejos cristãos, o único refúgio do divino se tornava a religião e seus espaços. Porém, o bufão é corrosivo às instituições de poder, pela sátira, pela inversão, pela corrupção, e carrega com ele o profano, em relação à religião institucional. Tais características e forças fizeram com que as instituições eclesiásticas se empenhassem em combater os bufões, expulsando-os, primeiramente, das igrejas.

Há registros documentados de ações católicas contra estes artistas. Tais documentos, ao mesmo tempo em que deflagram a caça a esses artistas, revelam a força que o jogo bufonesco/ grotesco tinha sobre o público e o pavor da perda do controle social por parte das instituições de poder religioso. A filosofia de vida do bufão não servia para as instituições controladoras, "Dormir, comer e deixar o mundo rodar. E isto representa a honra do bufão" (MOLINARI, 1985, p. 111)15. Com tal lema, percebe-se que falta o temor a Deus, a culpa, a obediência, a penitência - armas de manipulação das instituições religiosas -, falta ao trabalho, deveres sociais e moralidade - armas de obediência social.

Ainda, deve ser considerado que, mesmo dentro das instituições religiosas, o bufão não mudou seu aspecto: seu corpo-máscara deformado, pulsante e com hábitos lascivos representavam uma afronta para a moral religiosa. A igreja ou o bufão teria que sucumbir. Porém, sabe-se que "[...] o bufão
15

Tradução da autora:

"Dormire, magnare e lasciar correre il mondo. E questo rappresenta l'onore del buffone". 
nunca cai: ninguém jamais conseguirá culpá-lo ou fazer dele um bode expiatório, pois ele é o princípio vital e corporal por excelência, um animal que se recusa a pagar pela coletividade [...]" (PAVIS, 2005, p. 35) - desse modo, sem sucumbir, o bufão se retira, ou é retirado da instituição religiosa. A instituição mantinha o poder baseada no medo, na castração do prazer e na penitência, mas era conduzida por seres humanos passíveis de corrupção e esse era o embate, pois o bufão, com sua liberdade, convidava à corrupção e depois, estava lá para denunciar. Ele denunciaria os corruptíveis, os hipócritas que aproveitavam da riqueza, gula, luxúria e depois representavam a penitência e pobreza. Ele, o bufão, não estaria se denunciando, pois não fazia parte da moral social, mas denunciaria aqueles que se vestiam de falsa moral. Por todas essas razões, o terceiro espaço que o bufão ocupava, o das igrejas, foi sendo desocupado.

Apesar de sua condenação, seja por sua aparente loucura, seja pelo esconjuro religioso ou pela repugnância social/moral, o bufão exerce um fascínio naquele que lança um olhar sobre ele. Visto como portador da verdade, com sua aparente insanidade, tem licença de falar tudo a todos, sem ser alvo das leis morais. Através das possibilidades do riso, entre eles o da loucura, o bufão revela as intenções por detrás das convenções sociais e expõe a corrupção destas. A zombaria com o riso provocador traz consigo a crueldade da denúncia da verdade oculta, sempre sob a sombra de uma loucura ou jocosidade - o que causa a ambiguidade do poder de suas palavras.

Com a aparência metamorfoseada e metamorfoseante (por todas as forças que atuam em seu corpo máscara), aparentemente moribundo e agonizante, gangrena e pulsação entre vida e morte, entre excremento e fertilidade, entre putrefação e/ou gestação, o bufão é passagens de mundos, metamorfoses da matéria. Com pênis, seios, ventres inchados, intestinos e órgãos à mostra, o bufão é capaz de despertar sentimentos ambíguos de repulsão e compaixão. Alguns o veem como um pobre aleijão, um ser deformado digno de piedade, mas que causa, pela retórica compelida e mesmo pela deformidade, uma repugnância - talvez, uma autodefesa pela rejeição da dor causada pelos insultos verdades. Mas o verbo lançado também pode ser fruto da loucura e, então, o sentimento de piedade retorna, para logo após ter despertado em si, novamente, a repugnância e assim por diante, alternando no sujeito que o observa e com ele se relaciona sentimentos contraditórios.

O bufão é um ser perturbante com retórica corrosiva, de comoção e com intensas acentuações mímicas; ele tem a maestria da palavra e o uso potente do corpo no discurso heranças do mimo e do Sátiro (MOLINARI, 2007). Nas suas 
palavras estão afetos comovidos por seu corpo máscara que se emanam na atmosfera. A perspicácia da retórica, o uso da mímica, da ironia, da metáfora, do riso, do duplo sentido, do sarcasmo, da zombaria, do humor e do chiste sempre convém ao bufão; com isso, ele traz tudo aquilo que é cerebral para o plano físico, isto é, ele provoca uma reação física: o riso. Trazendo para o plano físico, ele retira o sujeito do campo do racional e começa a afetá-lo e, no reino dos afetos o bufão tem sabedoria empírica, tem conhecimento intrínseco, está no seu DNA imaginal - está no seu domínio.

Com poder de retórica, corpo máscara, teatro e metateatro (mímica), o bufão inverte a ordem estabelecida. Ele agride a sociedade, mas é necessário saber que essa agressividade não é física, mas sim moral, pois ataca os falsos moralismos, desencadeando uma tomada de consciência - e é nessa tomada de consciência que reside a agressividade e a crueldade. Com órgãos genitais, intestinos, feridas e deformidades à mostra, palavrões e obscenidades que se misturam a discursos filosóficos, existenciais e proféticos, o bufão infere uma reflexão sobre as relações humanas e suas estruturas. Apesar do bufão fazer uso de obscenidades é necessário deixar claro que ele não é um ser imoral, mas amoral - e esta diferença é muito importante, pois, para ser imoral o bufão deveria compartilhar da moralidade social e ele não compartilha: ele a denuncia. Deve-se lembrar que os símbolos obscenos advêm da parte sagrada do kômos e, ainda, ele os usa com a intenção de afrontar os tabus da falsa moralidade social, não para ser obsceno ou chocar pela obscenidade, pois para o bufão, na sua vida/jogo não existe o obsceno: tudo pode ser sagrado e/ou jogo.

Com sua gargalhada o bufão zomba e ri de tudo: do poder, da guerra, da fome, da riqueza, da pobreza, da morte, do Diabo, de Deus e do próprio homem, que cria as estruturas sociais para se encarcerar nelas (BALANDIER, 2006). Com sua gargalhada ele exorciza tudo o que poderia lhe causar pavor ou amedrontar, e assim ele sobrevive, pois "Quem ri do inferno pode rir de tudo" (MINOIS, 200o, p. 249) ${ }^{16}$. Com sua fome de vida, o bufão não necessita de autorização, aprovação, nem permite psicologias, pois ele "tem a superioridade da loucura suprema, da loucura universal, rainha do mundo" (MARTIN, 2003) ${ }^{17}-\mathrm{e}$ esta loucura universal, da potência cósmica criadora, também faz parte do Fundo Comum dos Sonhos.

O bufão é corpo-máscara; é um complexo de dinâmicas entre o Fundo Comum dos Sonhos e o Fundo Poético Comum, conectadas nas instâncias do jogo-festa-ritual, com discurso embebido na loucura universal e no grotesco, mediada pela maestria da retórica e do uso total das possibilidades do corpo no discurso, que tem em si a imaginação, o primitivo e o divino.
16.

Tradução de Christine Nicole Zonzon: "Qui rit de l'enfer peut rire de tout".

17.

Tradução de Christine Nicole Zonzon: "[...] a la supériorité de la folie, la folie universelle, reine du monde". 
O bufão festeja a vida no sentido mais ritualístico da festa. Seu corpo em evidência e dilaceração é presenteado ao ser humano, servindo-lhe de espelho para uma catarse. Em putrefação ou gestação, seu corpo prazenteiro emana e exala (-se em) festa, invocando uma percepção da dualidade do mundo e da vida humana (vida e morte). Nas suas entranhas e entranças o bufão traz o "princípio da vida material e corporal" (BAKHTIN, 1999). Nele e por meio dele, a festa se instaura, provocando no público que se permitir seguir seu bloco carnavalesco e coro a mesma comoção.

Por ser tão integrado à ancestralidade com seu corpo-máscara, grotesco, carnavalesco e prazenteiro, o bufão instaura a festa, invoca o ritual e joga com a realidade. Com sua presença seduz, trabalha no íntimo e no âmago, move afetos, instiga e age com destreza, perspicácia, sabedoria, amoralidade, liberdade, fascínio, malícia comovente e acessa a consciência da força popular rabelaisiana. Auxiliado pelo carnaval, riso e loucura, apresenta ao público a decifração da realidade social.

o bufão utiliza o riso em todas as suas vertentes. Sendo o riso ação física, ele pode ser uma ação de reação a um estímulo intelectual ou externo, ou uma ação espontânea provocada pelo próprio corpo, mas, em ambos os casos, o riso irá provocar uma ação sensível e subjetiva, a qual ultrapassa o momento do acontecimento, pois ele possui relações com dimensões abstratas à realidade, ele se conecta com a loucura universal, a rituais de transição de muitas culturas festivos, fúnebres ou de passagens etárias - ao prazer e à festa. Essa ação/reação física comporta e comove elementos arcaicos da alma.

As relações sensíveis conectivas com o bufão acontecem em muitos níveis, haja visto as relações do bufão, corpo-máscara, com o ritual, com Dionísio, com os Sátiros e com o coro. Alguns estudiosos associam o Trickster ao bufão. Se considerarmos a mitologia, o Trickster se avizinha muito ao bufão na concepção que interessa a esses encaminhamentos, pois é um ser antropomórfico, marginalizado, brincante, festivo, com características xamânicas, podendo ser, também, malandro, enganoso e "vingativo". Martin (2003) coloca Bufões, Tricksters e Xamã (cargo existente em algumas tribos) na mesma categoria, como sinônimos. É importante sublinhar que se tem como xamânicas as manifestações, ritos e práticas ligadas à natureza, ao plano espiritual, sobrenatural, energético e místico e, xamã, como o intermediário entre a realidade objetiva ${ }^{18} \mathrm{e}$ o fenômeno (BARRIO, 2005). Augras (2009) traz uma informação que vem ao encontro dos pensamentos que regem essa pesquisa: para ela, Exus e Pombogiras também estariam na mesma categoria dos Tricksters.
18.

Spolin chama de realidade objetiva aquela compartilhada em sociedade. Para saber mais, ler "O Jogo Teatral no Livro do Diretor", de Viola Spolin. 
Para esta pesquisa, Dionísio se conecta com Exu intensamente, de maneira subterrânea e arbustiva e, da mesma forma que os Sátiros se conectam com Dionísio, se conectam com Exu, por meio do caldeirão do imaginário, relacionados por um DNA imaginal que ultrapassa fronteiras culturais, de tempo-espaço e geográficas.

Dionísio, deus da transformação, dos ciclos da natureza, da transmutação do excremento em adubação e fertilidade da terra e da morte em vida, da festa, do banquete e do vinho, possui seus agenciamentos especiais; seu saber é enraizado, tão arbustivo quanto sua natureza, tão vivo e orgânico quanto sua fertilidade, tão intrínseco quanto a pulsação (MAFFESOLI, 1985). Tais características também são adequadas para Exu.

Os rituais dionisíacos eram rituais xamânicos, no sentido que buscavam a conexão com outra esfera, com o divino. Da mesma forma, os rituais de culto a Exu, o orixá da fertilidade, dos caminhos, da transmutação, da boca que tudo come e tudo deglute e devolve em fertilidade, também são xamânicos. Enquanto o Sátiro representava e incorporava Dionísio, o bufão representa e incorpora elementos sensíveis deste orixá tão dual e complexo que é Exu. Por meio de conexões, o bufão se torna um Xamã e comove nele uma ancestralidade afro-brasileira que é o Exu, tão mítico e controverso quanto Dionísio - mas essa complexidade polêmica é própria da natureza de ambos os deuses.

Alguns estudos referenciam o bufão como demônio, xamã/ feiticeiro e/ou trickster, mas de um modo pejorativo. E esta é uma visão bem cristã, uma vez que o bufão representa todo o excesso que a estrutura social reprime. O mesmo aconteceu com Exu - confundem-no com a personificação do mal e isto não é verdade. O mal, nesse caso, foi rotulado. Na Europa a tentativa de colocar Dionísio como o mal não funciona, pois ele já estava impregnado na cultura antes do cristianismo aparecer, então, já era popular e todos conheciam a sua verdadeira natureza. Exu é um orixá tão múltiplo e polissêmico quanto Dionísio e suas conectividades se dão em uma dinâmica recíproca e potente. Em nosso país, e também na América Latina, o cristianismo deflorou as crenças com os conceitos de pecado, temor, obediência, e toda e qualquer divindade que se opusesse a esta estrutura era vinculada ao "mal".

Nos rituais de Candomblé e Umbanda acontece a incorporação, na qual o Orixá ou Entidade se faz presente através da presença no "filho de santo" e este se torna a representação e a incorporação do próprio Orixá ou Entidade - do mesmo modo que acontecia com os que se faziam Sátiros, incorporando e representando Dionísio. Devemos lembrar que, em ambos os rituais, a dança é parte fundamental; ela comove 
a musculatura afetiva, a qual convoca a ancestralidade, juntamente com outros elementos (canto, tambor) que auxiliam nessa convocação/invocação.

No candomblé e na umbanda Exu é o primeiro a ser saudado. No terreiro sempre tem seu altar ou quarto e todos os filhos da casa devem prestar reverência a ele; isto porque Exu é responsável pela comunicação entre os deuses e os homens como Dionísio, na mitologia grega. Exu é quem abre e fecha os caminhos. Dentro da mitologia greco-romana, Dionísio ou Baco (correspondentes dentro do panteão mitológico antigo) não era apenas o mensageiro, aquele que levava e trazia mensagens entre deuses e seres humanos. Nos rituais a esse deus, o Sátiro o incorporava e na incorporação a comunicação se tornava interativa; deus e ser humano comungavam do mesmo corpo. A comunicação, então, acontecia em outros níveis, não somente por meio de mensagem, mas por meio da presença em/corpo/ação. Desse modo, Dionísio e Exu se tornam o vínculo corporificado entre seres humanos e deuses, e o sujeito, filho de santo ou Sátiro, é o Xamã, o suporte acolhedor e receptáculo que propicia a presentificação.

Enquanto para o candomblé ou umbanda a incorporação acontece com todos os orixás e entidades, na mitologia greco-romana o fenômeno acontecia somente com Dionísio. Porém, Exu e Dionísio se assemelham em outras características: no panteão afro-brasileiro, Exu é o orixá que tem preferência pelos prazeres humanos da festa, da embriaguez, do vício e do excesso - prazeres tão caros a Dionísio, também.

O fato de Dionísio permitir a comunhão entre deuses e humanos neste nível de compartilhamento de um corpo, isto é, permitindo que o ser humano experimentasse a sensação da divindade, da imortalidade (BRANDÃO, 2007), de subjetividades e sabedorias reservadas aos deuses, era uma afronta para a congregação do olimpo. A união entre imortalidade/mortalidade, deus/humano que acontecia na incorporação estabelecia o principal modo de comunicação que Dionísio agenciava entre as esferas da realidade e do divino. Tido como um deus popular e diverso dentro do mundo das divindades tradicionais do olimpo, seus cultos realizados no campo foram integrados aos ritos praticados em Atenas bem tardiamente, pois, diante de tamanha imprudência de agenciamento, era melhor que seu rito fosse integrado aos festejos do Olimpo com certa cautela (ROCHA, apud FÉLIX; GOETTEMS, 1989).

O vinho, a embriaguez, o excesso, a festa e tudo o que era do gosto popular e humano fazia parte dos ritos à Dionísio, como também o fazem dos ritos a Exu. Mas há diferenças nessa similaridade, e a diferença está no rito. Nos rituais a Dionísio, o vinho e a embriaguez propiciavam o êxtase para 
a comunhão com o deus acontecer. Nos rituais de Exu, na umbanda, o ato de beber acontece após o transe - isso quando o filho está inserido no rito, deixando de fora discussões sobre incorporações fora do rito ou por pessoas que estão em estado alterado de consciência por uso de álcool, ou ainda outros, e que acabam incorporando no rito. Nesse caso, ambos os rituais possuem a presença do álcool, mas agenciados de modos diferentes. No ritual de candomblé, na cerimônia compartilhada publicamente, o álcool pode ser oferecido ao público e é dado ao orixá em forma de oferenda; o Xamã não o bebe para incorporar, o transe acontece em um processo de possessão não induzido pela bebida, mas pela dança, canto e tambor.

Essa dualidade de Dionísio entre o humano e o divino é natural do próprio deus. Tal característica está na sua mitologia, pois teve duas gestações: uma foi na coxa do imortal Zeus e outra no ventre da mortal sêmele, o que o torna imagem fundante e fundada da/na comunhão e unicidade entre o ser divino e do ser humano (TORRANO apud FÉLIX; GOETTEMS, 1989).

Esta inversão do mortal em imortal que acontece no ritual de possessão e incorporação de Exu e Dionísio possui uma similaridade com os princípios do carnaval, reino onde a inversão de poder faz parte do jogo e a festa acontece. Nos rituais festivos de Dionísio e Exu é onde a maior inversão de poder acontece: a de um imortal em mortal e vice-versa.

Evoé e Laroyê, saudações e evocações potentes dentro de cada mitologia, são ambos ligados à fertilidade e procriação e possuem o falo como símbolo. Em se tratando de imaginário popular, ambos podem ser animalescos ou imagem e semelhança do ser humano, ambos possuem o bode com um dos animais totens ou a ser oferecido para sacrifício. Dionísio e Exu são vinho e cachaça em ritual ébrio festivo de transe e festa. A dualidade e ambiguidade estão presentes em ambos. Dionísio e Exu podem ser vingativos, apaziguadores, sedutores, sensuais, sexuais, guerreiros, sombrios e/ou solares, serenos, brincalhões, irônicos, mentirosos ou sinceros. Ambos potencializam a força que vai em direção a eles e se relacionam intensamente com o ritual e a festa, seja pela fertilidade, seja pela inversão da ordem e do poder, do jogo e da brincadeira do carnaval.

As mesmas potências que colocam o bufão em conexão com Dionísio, o colocam em relação com Exu. Importante ressaltar que essas conexões correm por transcursos subterrâneos. O bufão não é a incorporação de Exu ou de Dionísio, mas comporta e incorpora os princípios regentes desses deuses; ele é herdeiro desses deuses, herança vindoura por meio de um DNA imaginal. O ator bufão corpo-máscara deve buscar comover e afetar através de subjetividades advindas dessa ancestralidade festiva. 
Necessário se faz dizer que não se busca estabelecer uma correspondência entre Dionísio e Exu, mas se busca uma apropriação de conhecimentos, de compreensão de agenciamentos empíricos e ancestrais a partir do próprio referencial cultural, de uma experiência próxima a uma realidade de vivência. Se Maffesoli assinala que a Europa e o ocidente devem retornar ao saber dionisíaco (MAFFESOLI, 1985), por que não nos voltarmos para uma experiência ritualística que pode nos proporcionar este saber orgânico, enraizado e de transformação? Por que não nos apropriarmos desse saber exunisíaco com potência carnavalesca de exuberância, se temos o transbordamento da força do popular em muitas práticas tradicionais que nos propiciam a experiência viva de tais potências?

As conexões entre Dionísio e Exu podem entrar em minuciosas relações; traz-se aqui algumas delas, deixando mostrar que existem férteis elos conectivos fortalecedores de um saber intrínseco e empírico a serem explorados. Um saber profundo e sensível das transformações do corpo a partir de relações com os elementos da natureza, com a esfera espiritual e transcendente do ser humano.

O bufão corpo-máscara se conecta a Exu por meio das mesmas complexas relações que o conectam a Dionísio. Conectividades que extrapolam espaço/tempo, cultura ou geografia. Na verdade, são conexões/incorporações, realizações do Fundo Poético Comum que acontecem em níveis micro e macro, singular e plural, vindouras do Fundo Comum dos Sonhos por meio de um DNA imaginal. Nesta dinâmica o indivíduo é ele, é ele no mito, é ele com o mito, é o representante do mito, é o mito (ambiguidades dionisíacas, exunisíacas e, também, da máscara). É fácil de perceber que a maioria das considerações dizem respeito ao campo mitológico e se fortalecem nas esferas místicas do ritual, conectando, também, com o aspecto mítico e místico da máscara do bufão. Mas, sabe-se que todo universo sensível e imaginal alimenta a realidade, retorna ao imaginário, para depois retornar à realidade e assim por diante, formando a teia cíclica entre realidade e imaginário.

Muitas máscaras que integravam rituais realizados na Antiguidade e Idade Média, com o passar dos tempos, foram se espalhando, se desdobrando em possibilidades e potências, e continuaram a se manifestar nas montanhas, festas regionais e carnavais interioranos, mas também fizeram um caminho mercadológico. Em alguns momentos esse conturbado percurso se subdivide em profissional e ritualístico. Algumas vezes os dois percursos dialogam, se complementam. Em outras eles parecem muito distantes, e o diálogo, inverossímil. Mas esta dualidade contextual é parte do grande fascínio da máscara. 


\section{REFERENNCIAS}

ABELAR, Taisha. A travessia das Feiticeiras. A jornada iniciática de uma mulher. Trad. Terezinha Batista dos Santos. Rio de Janeiro: Record/Nova Era, 1996.

AUGRAS, Monique. Imaginário da magia: magia do imaginário. Petrópolis: Vozes e Editora da PUC, 2009.

BACHELARD, Gaston. A Terra e os Devaneios do Repouso. São Paulo: Martins Fontes Ltda., 1990.

BACHELARD, Gaston. O direito de sonhar. São Paulo: DIFEL, 1986.

BALANDIER, Georges. Le pouvoir sur scènes. Paris-FR: Fayard, 2006.

BAKHTIN, Mikhaïl. A Cultura Popular na Idade Média e no

Renascimento. O contexto de François Rabelais. São Paulo: HUCITEC, 1999.

BARRIO, Angel-B. Espina. Manual de Antropologia Cultural. Recife: Ed. Massangana, 2005.

BENISTE, José. Òrun Àiyé. O encontro de dois mundos: o sistema de relacionamento nagô-yoruba entre o céu e a terra. Rio de Janeiro: Bertrand Brasil, 1997.

BERTHOLD, Margot. História Mundial do Teatro. Trad. Maria Paula V. Zurawski, J. Guinsburg, Sérgio Coelho e Clóvis Garcia. São Paulo: Perspectiva, 2001.

BOTAS, Paulo Cezar Loureiro. Carne do Sagrado Edun Ara: Devaneios sobre a espiritualidade dos Orixás. Rio de Janeiro: Kainania Presença Ecumênica e Serviço Vozes, 1996.

BRANDÃO, Junito de Souza. O Teatro Grego - Origem e Evolução. Rio de Janeiro: Tarifa Aduaneira do Brasil, 1980.

BRANDÃO, Junito de Souza. Teatro Grego: Tragédia e Comédia. Petrópolis: Vozes, 2007.

BRONDANI, Joice Aglae. Varda Che Baucco! Transcursos Fluviais de uma Pesquisatriz: Bufão, Commedia dell'Arte e Manifestações Espetaculares Populares Brasileiras. Salvador-BA, Fast Design, 2014. ISBN: 9788588863705.

BRONDANI, Joice Aglae. Uma Fala Mítica - Reflexões Sobre Práticas Espetaculares Populares Brasileiras. In: BRONDANI, Joice Aglae (Org.). Scambio dell'Arte: Commedia dell'Arte e Cavalo Marinho. Teatro-Máscara-Ritual. Interculturalidades. Salvador: Fast Design, 2013. pp.13-30. ISBN: 9788588863378.

BRONDANI, Joice Aglae. Commedia Dell'arte e Cavalo Marinho: Transcursos Fluviais de uma Pesquisatriz. In: OLIVEIRA, Erico José Souza de (Org.). Tradição e contemporaneidade na cena do cavalo marinho. Salvador: EDUFBA, 2012. pp.113-122. 
BRONDANI, Joice Aglae. A Máscara: Do Bufão ao Clown. In: BRONDANI, Joice Aglae; LEITE, Vilma Campos; TELLES, Narciso (orgs.). Teatro-Máscara-Ritual. Campinas: Ed. Alínea, 2012. pp.71-90.

BRONDANI, Joice Aglae. Frevo, capoeira, samba ... Buffoni, Zanni, Arlecchino... caminhos fluviais: (um) universo e (um) imaginário. Ouvirouver, Uberlândia (Edufu), n. 4, 2008.

BURNIER, Luis Otávio. AArtede Ator: da Técnica à Representação. Elaboração, codificação e sistematização de técnicas corpóreas e vocais para o ator. Campinas: Editora da UNICAMP, 2001.

CAILLOIS, Roger. Les jeux et les hommes - Le masque et le vertige. Paris: Gallimard, 1967.

CAMPORESI, Piero. Rustici e buffoni. Cultura popolare e cultura d'élite fra Medioevo ed età moderna. Torino: Giulio Einaldi Editore s.p.a.,1991.

CONTIN, Claudia, MERISI, Ferruccio. Arlecchino e l'uomo selvatico: rapporto uomo-natura in antiche tradizioni carnevalesche. In: CONTIN, Claudia (Org.). Progetto Sciamano 2002. Maschere e Marionette dal Mondo. Pordenone: Ed. Provincia di Pordenone, 2002.

CONTIN, Claudia. Perseguindo Arlecchino. Trad. Joice Aglae Brondani. Ouvirouver, Uberlândia (Edufu), n. 4, 2008.

COSTA, Lígia Militz, REMÉDIOS, Maria Luiza Ritzel. A Tragédia. Estrutura e História. São Paulo: Ática, 1988.

CHACRA, Sandra. Natureza e Sentido da Improvisação Teatral. São Paulo: Perspectiva, 1983.

DUCHARTRE, Pierre-Louis. La Commedia dell'Arte au XVI siècle, en 1601... et en 1981. Le Recueil Fossard. Compositions de Rhétorique. Paris: Librairie Théâtrale, 1981.

FO, Dario. Manual Mínimo do Ator. RAME, Franca (Org.). Trad. Lucas Baldovino, Carlos David Slak. São Paulo: Ed. SENAC, 1999. GASSNER, John. Os Mestres do Teatro I. Trad. Alberto Guzik e J. Guinsburg. São Paulo: Perspectiva, 1974.

HUIZINGA, Johan. Homo Ludens. O jogo como elemento da cultura. São Paulo: Perspectiva, 1993.

LECOQ, Jacques. Le corps Poétique. Paris: Anrat, 1997.

MAFFESOLI, Michel. A Sombra de Dionísio: Contribuição a uma sociologia da orgia. Trad. Aluizio Ramos Trinta. Rio de Janeiro: Ed. Graal, 1985.

MARTIN, Serge; PEZIN, Patrick. Le Fou Roi des théâtres /Voyage en Commedia dell'arte. Saint-Jean-de-Védas: L'Entretemps, 2003. MINOIS, Georges. Histoire du rire et de la dérision. Paris: Fayard, 2000. 
MOLINARI, Cesare. Storia del Teatro. Roma: Editori Laterza, 16. ed. 2007.

MOLINARI, Cesare. La Commedia dell'Arte. Milano: Arnoldo Mandadori, 1985.

PAVIS, Patrice. Dicionário de Teatro. Trad. J. Guinsburg e Maria Lúcia Pereira. São Paulo: Perspectiva, 2005.

RoCHA, Maria Christina de Caldas. O Discurso Político no Édipo-Rei de Sófocles. In: FELIX, Loiva Otero; GOETTEMS, Míriam Barcellos (Orgs). Cultura Grega Clássica. Porto Alegre: Editora da UFRGS, 1989.

TAVIANI, Ferdinando. La Commedia dell'Arte e la Società Barocca. La fascinazione del teatro. Roma: Bulzoni Editore, 2. ed. 1991.

TAVIANI, Ferdinando. O Teatro de Meyerhold. Trad. Aldomar Conrado. Rio de Janeiro: Civilização Brasileira, 1969.

TAVIANI, Ferdinando; SCHINO, Mirella. Il segreto della Commedial dell'Arte. La memoria delle compagnie italiane del XVI, XVII, XVIII secolo. Firenze: La Casa Usher, 1982.

TESSARI, Roberto. Commedia dell'Arte e rituais não cristãos. Trad. Joice Aglae Brondani. In: BRONDANI, Joice Aglae (Org.). Scambio dell'Arte: Commedia dell'Arte e Cavalo Marinho. TeatroMáscara-Ritual. Interculturalidades. Salvador: Fast Design, 2013. TESSARI, Roberto. Commedia dell'Arte: La Maschera e l'Ombra. Azzate: Ed. Mursia, 1981.

WILLEFORD, William. Il Fool e il suo scettro. Viaggio nel mondo dei clown, dei buffoni e dei giullari. Trad. Daniela Bonelli. Bergamo: Moretti \& Vitali, 2005. 


\section{Sobre a autora:}

Joice Aglae Brondani: Pós-Doutorado UNITO (CAPES Proc. BEX6818/14-5; 2015-2016) - Máscaras Femininas da Commedia dell'arte e Cultura Tradicional Popular Brasileira, Mitologia de Iansã e Pombogira). Pós-Doutorado PRODOC - CAPES, PPGArtes-UFU - Comicidade e Criação - Commedia dell'arte, Cultura Tradicional Popular Brasileira e Palhaço (2011-2014). Doutora pelo PPGAC-UFBA (2006-2010) - Bufão, Commedia dell'Arte e Práticas Espetaculares Populares Brasileiras; intercâmbio com a Università di Roma Trè e Scuola Sperimentale dell'Attore, Mestre pelo PPGAC-UFBA (2004-2006) - Clown e Processo de Encenação; intercâmbio com a Universitè Paris X. Formada em Direção Teatral (2000) e Licenciatura em Artes Cênicas (1999) pela UFSM/RS. Autora e organizadora de livros. Autora de artigos. Fundadora da Cia Buffa de Teatro (1998...), grupo de pesquisa em Artes Cênicas. Fundadora da Bottega Buffa CircoVacanti, grupo de commedia dell'arte de Trento-IT (2010-2014). Integrou o corpo de atores do espetáculo SlavaSnowshow, do palhaço russo Slava Polunine, na temporada Paris 2011. Integrou o corpo de professoras e atrizes da Scuola Sperimentale dell'Attore, dirigido por Claudia Contin e Ferruccio Merisi, nos anos de 2008 e 2009. 